Meta

Journal des tradlucteurs

Translators' Journal

\title{
Some Thoughts on Professional Status for Translators
}

\section{A. Sinclair}

Volume 14, numéro 2, juin 1969

URI : https://id.erudit.org/iderudit/004158ar

DOI : https://doi.org/10.7202/004158ar

Aller au sommaire du numéro

Éditeur(s)

Les Presses de l'Université de Montréal

ISSN

0026-0452 (imprimé)

1492-1421 (numérique)

Découvrir la revue

Citer cet article

Sinclair, D. A. (1969). Some Thoughts on Professional Status for Translators. Meta, 14(2), 89-92. https://doi.org/10.7202/004158ar d'utilisation que vous pouvez consulter en ligne.

https://apropos.erudit.org/fr/usagers/politique-dutilisation/ 


\section{some thoughts on professional status for translators}

E.C. Hughes ${ }^{1}$ defines professions as \& those occupations in which caveat emptor cannot be allowed to prevail and which, while they are not pursued for gain, must bring their practitioners income of such a level that they will be respected, and such a manner of living that they may pursue the life of the mind ». Translation would appear to qualify under this definition in everything except perhaps the matter of income. Although average earnings have increased considerably over the last decade, there are undoubtedly many translators still living close to the so-called poverty line, while many others who might like to make this activity their sole means of livelihood feel they can only afford to practice it part-time, as a secondary source of income.

However, there is more to the question than this. Even a well-paid practitioner of a profession, in the above sense, is somehow non-professional if the factor of expertise in his work goes unrecognized.

This point may best be illustrated by reference to specific cases. At one extreme, for example, there is the case of a prominent translator who is employed by a large chemical firm in the U.S.A. This man is regarded by the research workers, engineers and executives of the company as the expert on foreign language matters. His salary, of course, is commensurate, but the important point is that he is accepted as an equal in the high echelons of the organization precisely because of his skill and knowledge in a difficult field. There can be no doubt as to his professional status.

A commoner situation, unfortunately, is that of the individual in a large bureaucratic establishment employing dozens to hundreds of translators. These are generally divided into smaller groups under the supervision of revisers, editors or administrators who assign, check and forward the work and who may or may

1. "The Professions in Society", Canadian Journal of Economics and Political Sciences, XXVI, 1 (1960): 54-61. 
not be versed in the intricacies of translation per se. The tender plant of professionalism has a very hard time indeed to survive in such surroundings.

In the words of T.H. Marshall ${ }^{2}$ : "The professional man is distinguished by the fact that he does not only give his skill. He gives himself. His whole personality enters into his work. \#Applied to the translator this means that his expertise depends not just on his skill in transposing between two or more languages, but derives from everything that he has become and learned in the course of his life. To any given text he is ready to apply whatever part of his past experience and education is called for, and if still more information is needed he spares no effort to acquire it.

Now in the large office these facts go largely unnoticed. The client, usually someone in a remote department, forwards his request for a translation through channels and eventually receives back a neatly typed product, duly stamped with the insignia of the translation department, but otherwise as impersonal as a xerox copy. He could not, even if he wanted to, compliment the translator on a job well done.

The translator, in turn, gets an equally depersonalized document to work on, often one that is torn from context. It is usually impossible for him to seek enlightenment either from the requisitioner or the author, while the reference sources available to him are frequently inadequate.

Such conditions are hardly conducive to the growth of a professional attitude, to the giving of oneself in Marshall's sense. Indeed, the natural response of the intelligent person can only be to grind out his thousand or two thousand words of passable target language per day and then, at the five o'clock signal, to head for the nearest tavern. A «shop » of this kind could, and perhaps should, be unionized, but professionalization is something else.

To some extent these remarks apply also to free-lance translators. The individual who solicits his own contacts obviously has every opportunity to develop professional translator-client relationships, but those who rely on certain agencies for their commissions are not so favourably situated. For obvious reasons it is in the interest of the agent to keep clients and translators apart, and again it becomes difficult for the one to put his best effort into the work and for the other to appreciate the calibre of the man or woman by whom he is being served.

This situation will continue to exist as long as the agency is conceived of as a normal commercial enterprise seeking the largest possible profit by buying cheaply and selling dearly. There are two feasible alternatives: first the cooperative, where a number of translators with complementary language and subject skills share a common market, and second the «ten-percenter » type of agent whose function is simply to find and steer potential clients to suitable translators in return for a reasonable share of the fee.

How can the overall situation be improved? It has been suggested, among other things, that the various provincial translators' societies apply to their respective legislatures for charters giving them powers to «control 》 the profession, in

2. "The Recent History of Professionalism in Relation to Social Structure and Social Policy ", Canadian Journal of Economics and Political Science, V, 3 (1939): 325-340. 
other words to license translators. The principal control measure would be to examine all candidates for admission to the profession and to refuse membership in the society, and hence the licence, to all who fail to demonstrate a certain minimum competence. This, so the argument runs, will eliminate the marginal practitioners who give translation a bad name, and will raise public confidence to the point where this calling will be recognized as a true profession.

There are two main objections to this course of action as I see it. Firstly it asks that rather considerable powers be conferred on a relatively unknown occupational group which, unless carefully restrained, might conceivably use them to restrict the numbers practising the occupation and force up the prices for its services. Legislators might justifiably fear this possibility, especially in areas where translators even now enjoy the benefits of a «sellers' market». Therefore any legislation that gets passed is likely to be so hedged around with safeguards that it will be relatively ineffective as far as real control of the profession is concerned.

More importantly, with its inevitable emphasis on minimum standards this course of action fails to get at the root of the problem. For the essence of professionalism is not the possession of a basic, easily measurable skill, but of a total expertise. The person who is just barely able to produce a satisfactory translation of a simple business letter, for example, is not and probably never can be a professional translator. The professional should be able to do the letter, so to speak, with his eyes shut, but at the same time the capable of a real tour de force with much more difficult material. In other words he must exhibit a definite talent.

Even so, the all-important element of professional self-esteem will continue to languish as long as good work goes unrewarded by anything but the weekly wage. It is only human, and indeed entirely justified, for the translator to desire recognition of his special skill, his general knowledge, his ingenuity and the extra effort he willingly puts forth when the circumstances require. However, so long as considerable numbers of translators are regimented in assembly-line systems, just so long will an unprofessional spirit prevail.

The professional societies could do a great deal towards rectifying these conditions by helping to persuade administrators of the need to unplug their bureaucratic channels and enable translators and clients to communicate with each other.

A recent study of trade and professional associations in the United States ${ }^{3}$ had this to say: «A recommendation of this study is that Associations establish such high standards for their professional degrees that further extension of licensing by federal or state authorities will not be needed to protect the public interest. » It is argued that admission to a profession should be primarily the concern of training institutions, i.e., in our case Universities, where there is ample time to observe students' overall performances and to assess their potentialities for the future. This is essentially the role of medical schools, law faculties, etc. However, it is also desirable for the professional societies to offer graded examinations at

3. J.F. Bradley, The Role of Trade Associations and Professional Business Societies in America, University Park, P.A., Pennsylvania State University Press, 1965. 
suitable times and places, against which one who has already graduated to practice can measure his continuing progress, and in the event of success be rewarded with an appropriate professional degree.

One obvious advantage of such a system, assuming its impartial application, would be to make it extremely difficult to hold back promotions from deserving employees in the large translation bureaux. Similarly, expert free-lance translators would find new doors opened to them, while commercial agencies would find it advantageous to pay out a larger share of their profits in order to retain the services of individuals holding higher degrees.

In a brief discussion such as this only a few main points can be touched upon. It remains for those involved in the work of organizing to consider them in detail and to push forward towards desirable goals wherever possible. Most important of all, however, is for the rank-and-file translator to realize the essentially professional character of his occupation and to insist on its proper recognition by clients, employers and representatives alike.

D.A. SINCLAIR 